\title{
LANGUAGE LEARNING IN HIGHER EDUCATION
} Journal of the European Confederation of Language Centres in Higher Education (Cercles)

EDITORS-IN-CHIEF

Carmen Argondizzo

Università della Calabria

Italy

E-mail: carmen.argondizzo@unical.it

Gillian Mansfield

Università di Parma

Italy

E-mail: gillianmansfield125@gmail.com

\section{ASSISTANT EDITORS}

Fiona Dalziel

Università degli Studi di Padova

Italy

Annick Rivens Mompean

Université de Lille

France 
ABSTRACTED/INDEXED IN Baidu Scholar, Cabell's Whitelist, CNKI Scholar (China National Knowledge Infrastructure), CNPIEC - cnpLINKer, Dimensions, EBSCO (relevant databases), EBSCO Discovery Service, Educational Research Abstracts Online, ERIC (Education Resources Information Center), ERIH PLUS (European Reference Index for the Humanities and Social Sciences), Genamics JournalSeek, Google Scholar, IBR (International Bibliography of Reviews of Scholarly Literature in the Humanities and Social Sciences), IBZ (International Bibliography of Periodical Literature in the Humanities and Social Sciences), J-Gate, JournalTOCs, KESLI-NDSL (Korean National Discovery for Science Leaders), Linguistics Abstracts Online, Microsoft Academic, MLA International Bibliography, MyScienceWork, Naver Academic, Naviga (Softweco), Norwegian Register for Scientific Journals, Series and Publishers, Primo Central (ExLibris), ProQuest (relevant databases), Publons, QOAM (Quality Open Access Market), ReadCube, Research into Higher Education Abstracts, SCImago (SJR), SCOPUS, Semantic Scholar, Sherpa/RoMEO, Summon (ProQuest), TDNet, Ulrich's Periodicals Directory/ulrichsweb, WanFang Data, Web of Science - Emerging Sources Citation Index, WorldCat (OCLC), Yewno Discover

The publisher, together with the authors and editors, has taken great pains to ensure that all information presented in this work reflects the standard of knowledge at the time of publication. Despite careful manuscript preparation and proof correction, errors can nevertheless occur. Authors, editors and publisher disclaim all responsibility for any errors or omissions or liability for the results obtained from the use of the information, or parts thereof, contained in this work.

ISSN 2191-611X · e-ISSN 2191-6128

All information regarding notes for contributors, subscriptions, open access, back volumes and orders is available online at www.degruyter.com/view/j/cercles

RESPONSIBLE EDITORS Carmen Argondizzo, Università della Calabria, Italy, E-mail: carmen.argondizzo@unical.it and Gillian Mansfield, Università di Parma, Italy, E-mail: gillianmansfield125@gmail.com

JOURNAL MANAGER Alexander Görlt, De Gruyter, Genthiner Straße 13, 10785 Berlin, Germany, Tel.: +49 (0)30 26005 - 234, Fax: +49 (0)30 26005 - 250 .

E-mail: alexander.goerlt@degruyter.com

RESPONSIBLE FOR ADVERTISEMENTS Alexander Görlt, De Gruyter, Genthiner Straße 13, 10785 Berlin, Germany. Tel.: +49 (0)30 26005 - 170, E-mail: anzeigen@ degruyter.com

C 2021 Walter de Gruyter GmbH, Berlin/Boston

TYPESETTING TNQ, Chennai, India

PRINTING Franz X. Stückle Druck und Verlag e.K., Ettenheim 


\section{Contents}

\section{Articles}

Carmen Argondizzo and Gillian Mansfield

Celebrating Cercles: introductory notes to 30 years of professional activity in the field of language learning and teaching -259

\section{Voices from current and past CercleS Presidents}

David Little

Plurilingualism, learner autonomy and constructive alignment: A vision for university language centres in the 21st century - 271

\section{Maurizio Gotti}

Recent developments concerning the use of English for teaching and research purposes -287

\section{Johann Fischer}

The underlying action-oriented and task-based approach of the CEFR and its implementation in language testing and assessment at university -301

\section{Sabina Schaffner}

The language centre as a laboratory for innovation - 317

\section{Liliana Szczuka-Dorna}

The development of a Language Centre. An example of best practice in a historical perspective -327

\section{Voices from European Language Centres and beyond}

Carmen Argondizzo, Anna Maria De Bartolo, Alessandra Fazio, Jean M. Jimenez and Ida Ruffolo

Academic, cultural and social growth through the language of websites: A challenge for European University Language Centres — 341 
Salwa Mohamed

An evaluation of culture teaching and learning in a Uniwide Language

Program: Teachers and students' perspectives — 357

Åsa Mickwitz and Marja Suojala

Learner autonomy, self-regulation skills and self-efficacy beliefs - How can

students' academic writing skills be supported? - 381

Annemari Heinonen and Satu Tuomainen

Enhancing assessment in the recognition of prior learning with

digitalisation 403

Alice Spencer and Anna Bussi

The university language centre as an open-badge issuer: New directions in ESP assessment and accreditation -421

Alberto Andujar and Maria Soledad Cruz-Martínez

Cognitive test anxiety in high-stakes oral examinations: Face-to-face or computer-based? 445

Jennifer Ament, Júlia Barón-Parés and Carmen Pérez-Vidal

Exploring the relationship between motivations, emotions and pragmatic marker use in English-medium instruction learners - 469

Sharon Chang

Raciolinguistic ideology in first-year university (non)heritage Chinese classes 491

\section{Reports}

Beverly-Anne Carter

Taking research from periphery to core in a Caribbean Language Centre -511

Jaana Sorvari, Satu Rusko, Nina Jackson and Hanna-Leena Ainonen

Integrating entrepreneurial working life skills with foreign language teaching two cases from the University of Oulu — 521 